\title{
ミクロネジアの楖子葉製編多籠
}

杉浦健一

\section{1. 序說}

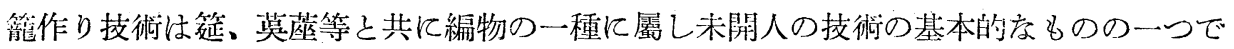
ある。從つて編物は早くから研究が行はれた。就中編み篧の研究は O. T. MATON 飞依つ てアメリカ・インデアンの籠飞關する徹底的究明をなされを結果非常整備した。東南ア ジアから太平洋の島々飞掛けては寒溫帶の樣に毛皮、動物繊維が比較的多く利用されない

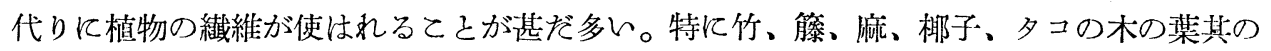

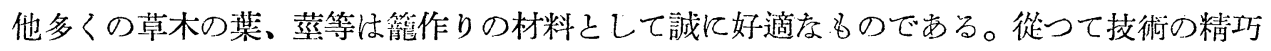
であるか否か、藝術的であるか否か戊處では言及しないとしても南洋方面では尠くとも

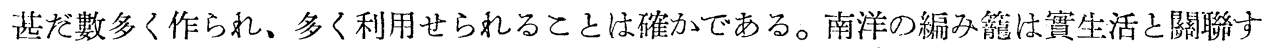
る所が甚だ深いと云ふ點のみからでも研究の價值が大きい。その上日本、支那等のものか らマレイ、更にメラネジア、ミクロネジア土人の籠をで何等か一連の關係のあるものとし て研究出來る。竹製微の如きは日本、南支那、印度支那斗島より東印度、フィリッピン。

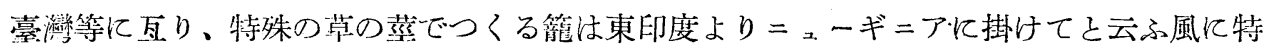
定の材料之技術它持つを種々の籠が一定地域に分布してわる。楖子葉製の籠は斯かる種類 の瀪の代表的烄ものの一つである。材料はココ梛子の葉を用ひるため使用する地域が一定 してるる。技術も葉柄を使用して斜め編みてすると云ふ點で一定してるる。ての編み方は 䍡だ單純ではあるが特異なるのであるため普通の基本的編み方の分類には出てるない。斯 くの如く定つた材料をもつて、特定の技術に依つてつくられた籠中今迄普通㐳研究された 編物の中には說明されてるない特殊を基本的編み方に屬するココ梆子葉製編み籠て就いて 述べる。

\section{2. 棷子葉製籠編み技術}

此の籠の行はれる地域はココ楖子の栽培される地方に限られてるる。但しアフリカ、南

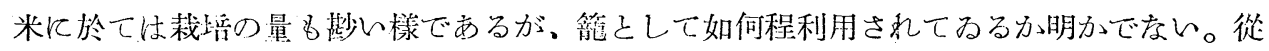
つて主として東印度諸島、メラネジア、ミクロネジア及びポリネジアのものが考へれる。 
本稿㤝之等の地方中特にミクロネジアのものに良つて考へる。ミクロネジアに於けるココ

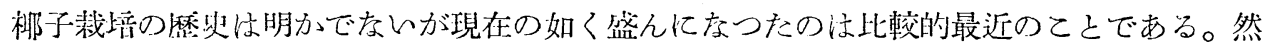

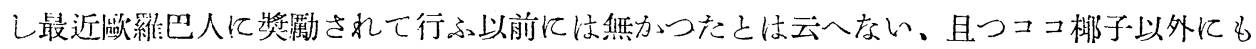

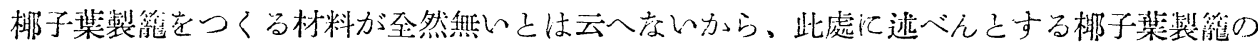
製作は最近ココ柳子が盛んに栽唔されると共に起つた或は奘入されたとは斷定出來ない。 何等かの素地が前からあつたらうと想定せられる。然し現在程多く使用せられる㥞になつ たのは確かにココ梆子が盛んに栽培される栐に店つてからである。

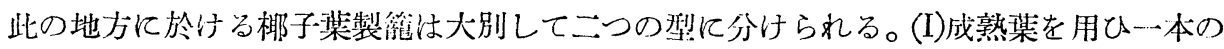
泟柄全澧をそのま〉使ふもの、(II) 失熟葉を用ひ一本の葉柄を二つに割り兩者を組み合せ て編むものである。何れにしても椰子葉製箈の特色は葉柄についたま」の一桨一渠の葉を

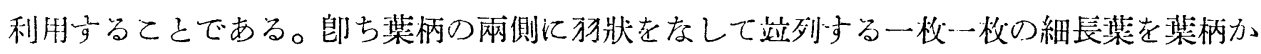
ら切り離さ剠附いたま小編む。從つて一般の箷作りでは經の材料と緯の材料とをバラバラ に離して、自由にして後組み合せるのに對し、柳子栠製簿の場合は經となる材料も紿と交 る材料も同じく一つの集柄に同一方向を向いて附いてるる葉である。從つて一つ通きの棨 を反對方向に折つて組み合せる外に方法がない。斯くして編み方は對角線をなす樣に組み

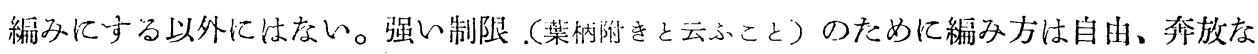

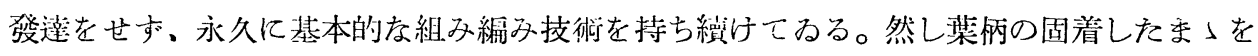
利用するととは、材料を直ぐに編みにか」れるやうに整借し、仕事を容易ならしめると共

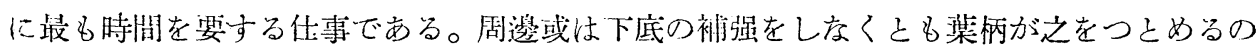

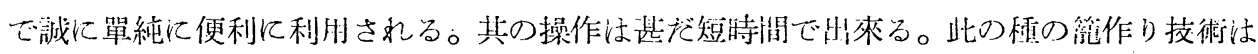

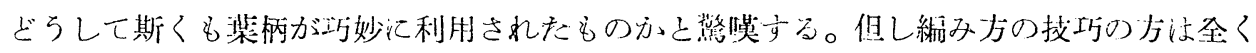

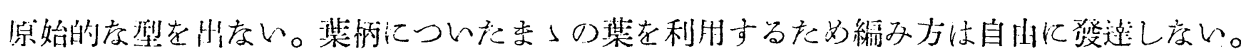

\section{3. 成熟葉を使用するもの}

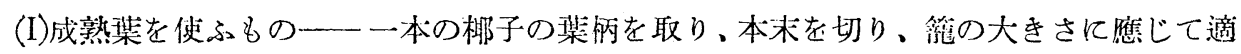

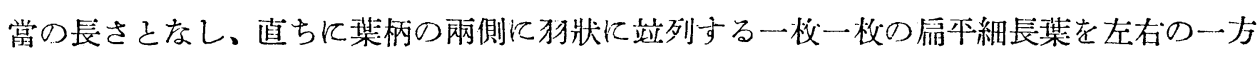

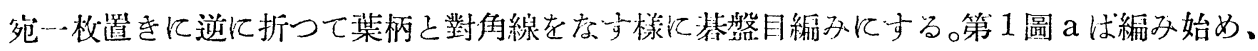

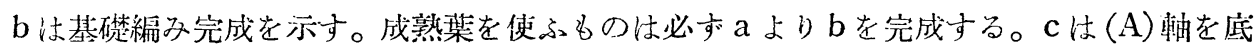

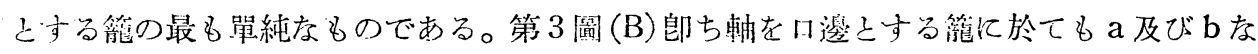
る基礁編みは第 1 圖郎ち (A) 軸を底こするものと全然同一である。成熟葉を使つてする最 为單純孝科基盤目編みは總べて斯かる基礎編みを經て行はれる。乙れを分類すると更に 

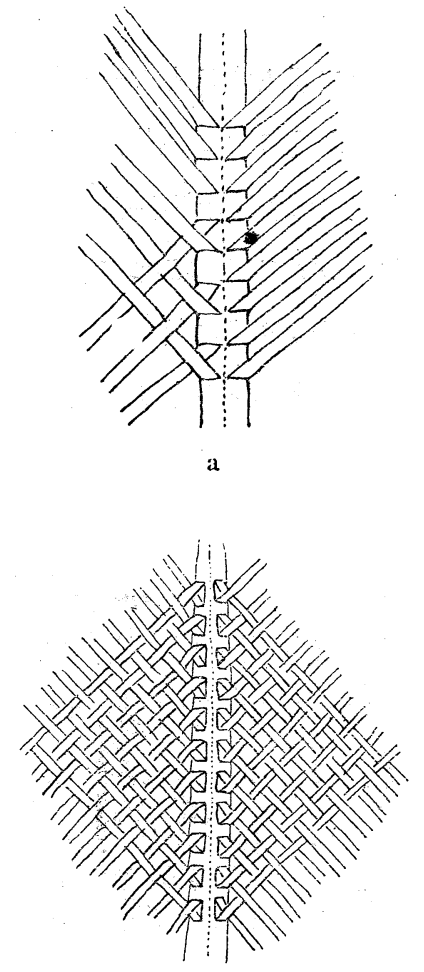

b)

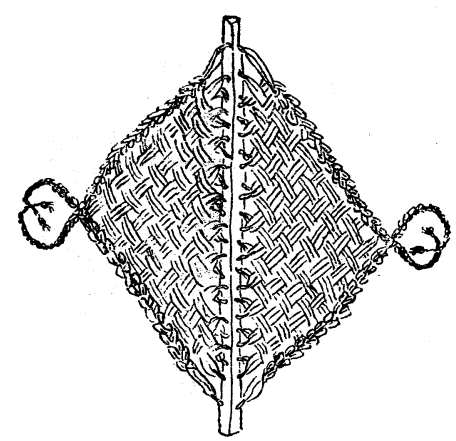

c

架 1 田进

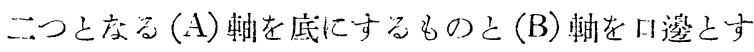
るものとである。

(A) 軸を底とするもの一一机は第 1 圖 a 飞示吉如

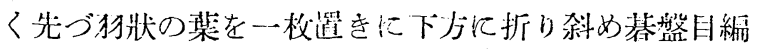

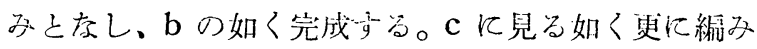

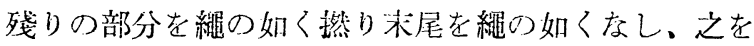
結んで罡く。第 2 圖 a の如く装柄郎ち軸を下底にして

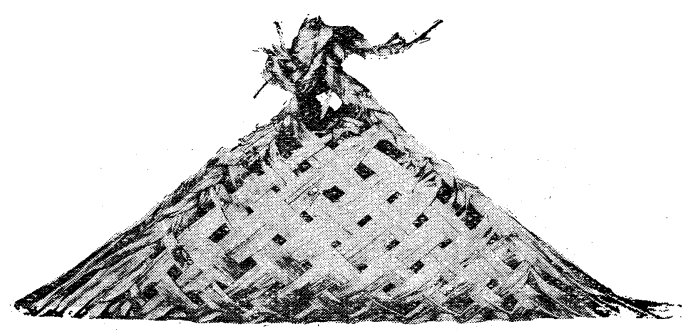

a

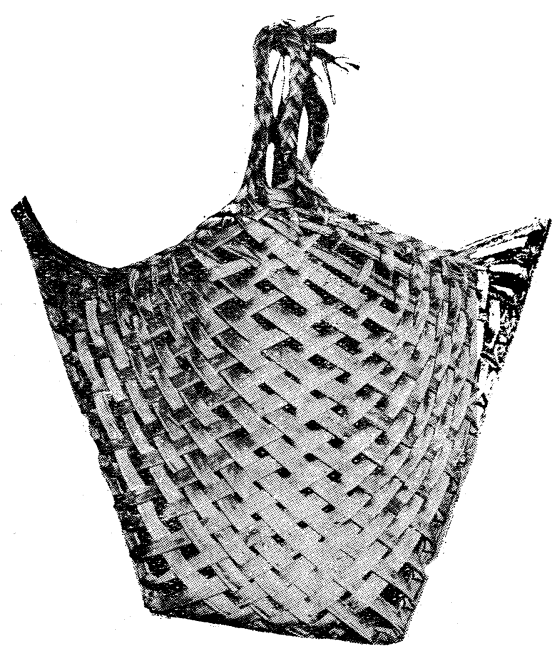

b

分 2 棦

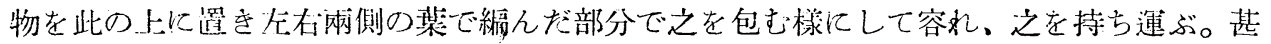

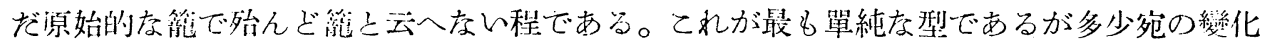
をなし進んだものは紽の體をなす。第 3 圖b注此の程の內の最も進んだものである。此等

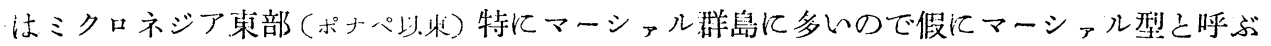




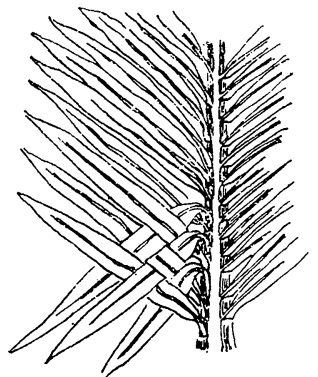

a

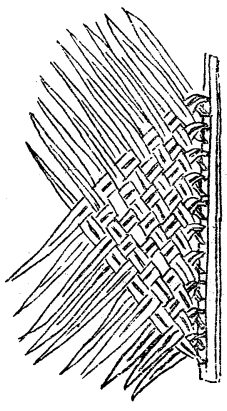

b

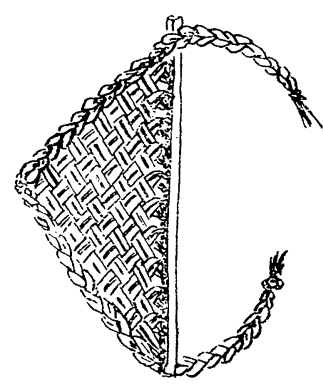

c

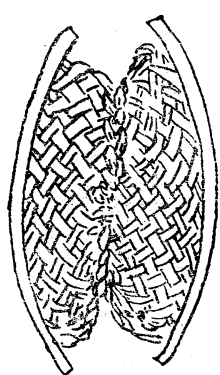

d

纱; 3 喕

た部分は兩端て传の如くなす。出口の度い三角袋の如きものの装 柄部分媳ち軸を中心より二つに切り割ると $\mathrm{c}$ 圖の如く大をな口を 開き、軸が大丈な口邊となり底の三角な箈となる。为物で縱沉割

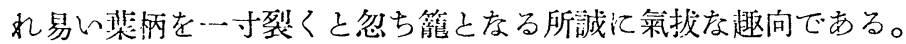
之之原理は全く同じであるが基礎編みを底が三侍之なる核にせず 四解にな㥞にしたのが四㑇底的ち一般型で市る。之はミクロネ ジアに於てはマーシァル群島を除く一般に見られるものである。 特に中央站沉酉方カロリンの島々で汒多く用ひる(第 4 圆)。

(B) 此を口邀と守るもの一一第 3 圖 に示すものがその一つの代表である。 之の中が更に(1)四角底 (一般业) 之(2) 三角底(トラック型)との三つに分れる。 三角底はトラック息に於て代表的比見 られるので筆者はトラック型さ呼ぶ。 第 3 圖は之を製作する行程を示すもの である。 $\mathrm{a}$ 圖及び $\mathrm{b}$ 圖の基礎編みは(A) 軸を底とするものも全然同じである。 $\mathrm{c}$ 圖に於て左右兩側の基礎編みを終つ たものを二つ併せ三觕底の出口の度い 袋の如く、兩 側の䋴み殘し の部分を繩の 如く撚り餘つ

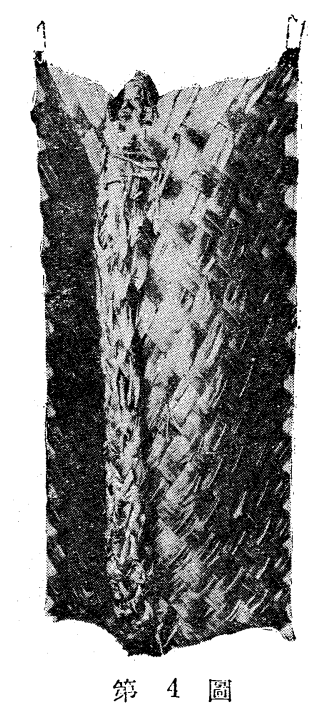

\section{4. 未熟枈を使用するもの}

次に (II) 米熟葉を用ひ一本の䕀柄を縱に二つに裂いて二つとなし之丧組み合せて編むも の就いて述べる。之は栁子葉が成熟せ称黃色をなし、葉は二つ折りとなつてるるもの

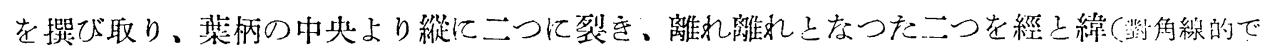

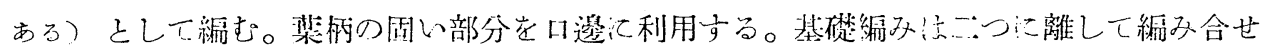
るのであるから (I) の如く單純でをく全く別の型崖疗す。之は淂來上りの形狀、及び最後 


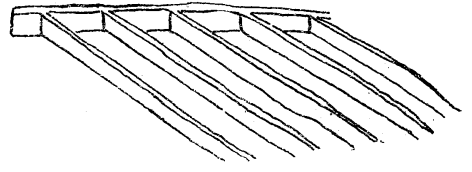

a

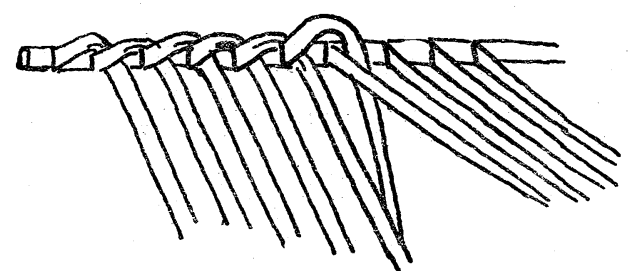

b

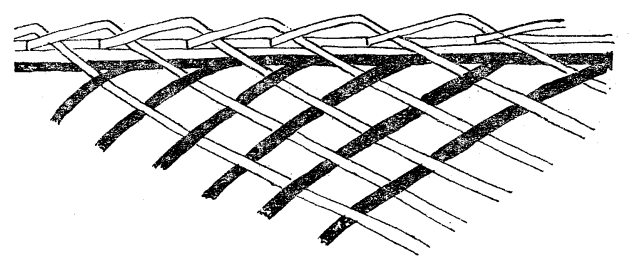

c

符 5 圖

の編み終りを處分する仕方に依つて多種 類の戀化が出來るが基礎編みの原則は同 じである。乙の基礎編みは第 5 圖 $\mathrm{a}$ の如 く一本の若い棐柄をとり、之を縱に二つ に裂き其の一方をとり、b 圖の如く本の 方から一葉一葉すぐ前の葉の葉柄附け根 の直ぐ下をくぐらせて、波狀を描いた經 のもの・(c圖で白摧にするもの) 亿對し、a 圖の如き無加工のもの(c圖では黑满とす) をそのま〉方向を逆にし緯とをして二つ を組み合せ、之を口邊として口邊から底 の方に向つて斜め基盤目編办化するとc 圖の如くなる。之が基礎編みである。第 6 圖は寫眞飞依つて之を示す、上緗に波 狀につくつた經の材料 (c圖で白描にする) こその下に c 圖で黑指にした緯の材料と を組み合せをものである。此の種のものは總べて葉柄を口邊己をし、此處より編み初める もので何れも底於て編み殘りを處分するのである。ての基礎編みは第一種の基礎編み己 ちがひ斜めではあるが、經と緯との二つの材料を離して使ふから、自由となり複雜となり 得る。之に屬するものは種類最も多く且つ廣くミクロネジア全般に行はれてるるが、其の 狀態、大きさ、編み殘りの處分の仕方は細く云へば谌だしく多樣であつて、單純な分類を して整理するのに困難を感する程である。

材料之なるココ棚子の若葉は勿論その葉柄も若い時は比較的柔軟であるから、圓型、角 型と云ふ風に固定した形を作るよりも袋の如くペッチャリしてしまふ場合が多いが、然る に圓形に固定した容器としての型を保つもの子可をりある。斯かるるのは比較的固く丈夫 となつた葉柄を採つてつくる。編み方より分類すれば固定した形を持つか否かは關係をい 譯であるが。定形を保たしめるには材料だけではなく編み方技術にも依る所が多い。

緛み方に依る分類恃主として底侥つた螎み殘し部分の處理方法より行ふ。

（A）編み殘し部分を繩の如く撚つて編み籠の內側飞通し末端て結び玉をつくつてとめて 置くもの。文が最も一般的孝方法である。二つの經緯軸を併せて編む第二類の未熟葉製編 


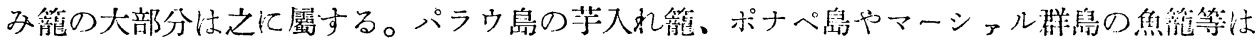
之屬す。

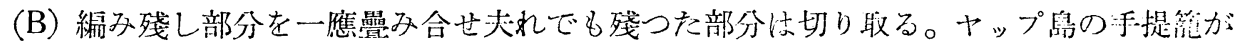
之に屬する。

（C）螎み殘し部分を編んだ部分の中に折り込んでしまふもの。他の總べてが編み殘し部 分を色々の形で不手際に處理するのに對して、之之（5）本底の梛子葉籠とのみは編んだ部

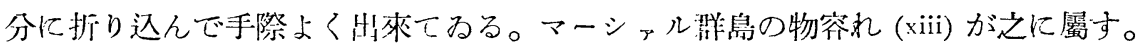

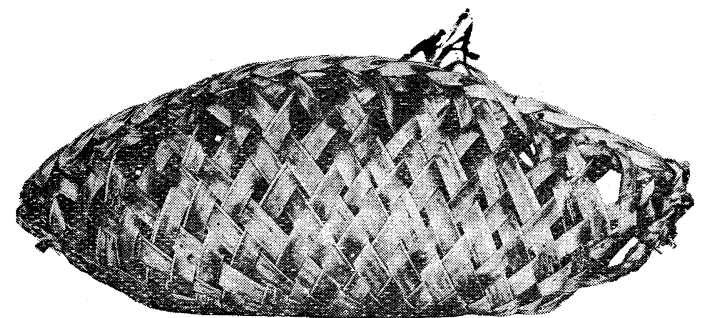

第 6 㨽

(D) 固定した圆形の籠で底の編み 殘し部分を特色ある方法で處分して るる。第 7 圖は之を示す。マーシっ ル群島のマゴモグ 澱粉を入れる籠 (ix) が之に屬す。此の種類の箈统ポ リネジアに多く見出される。マーシ ァル群島より西には全く見山されな

い。郎ち東方ポリネジアとの關係を示す證據の一つとなる。

（E）平底の梛子葉䇠——柔軟な梛子䒚若葉で固定した圓形を保つことのみでも容易でな レのに、口邊が圆形である上に胴を四角となし四つの稜をつくり、底は平底となす困難な 技術を要する。編み殘し部分を平底に編んだ部 分の上に重奴て折り疊む。從つて手際良く出來 て居る。平底笠をつくることは柳子葉製簿とし ては非常に困難と犠牲とを冒して作るものであ る(䇷 8 圖)。梆子葉製簿を斯かる形のものにつ くること汢、乘軟孛材料依つては自然の發達 とは考へられない。恐らく籚その他の固い材料 で作られた本底で四角棱のついた箈が以前から あつて、其れを模して楖子葉の柔軟な若葉で無 理して之をつくつたのであらう。

以上の外にもマーシャル群島の砂利運び籠。

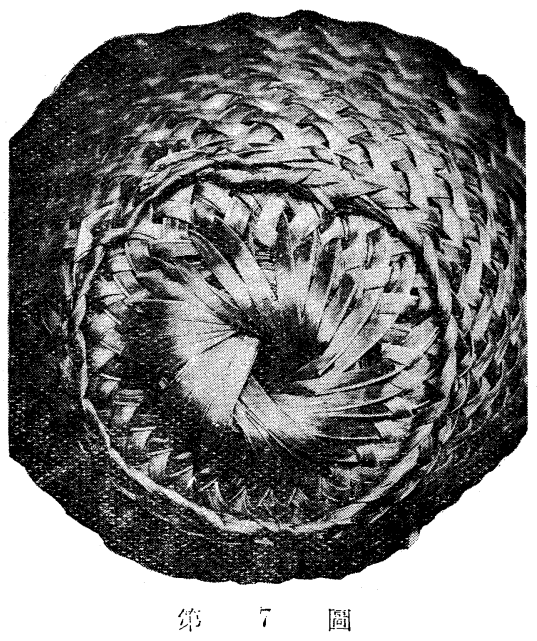
ヤップに於ける小形の食物容れ、其の他第一類にも第二類江も屬せ收もの、郎成熟葉を使 用する點第一類に入るが、葉柄の固い部分を去つて製作し、經と緯の二つの材料を斜めに 
編み合せる原則が第二類に㻿するので此處では第二:類の變異形とした。

\section{5. 楖子葉製編み籠の名稱と用途}

箷一般を示多名稱壮大體に於て無いと云入る。花、果實等を總稱する名稱がなく、楖子 の花、パパイヤの花等㑬々の花、パンの實、梛子の實等個々の名稱があるのと同じである。 從つて梛子葉製籠を一括して之に名稱を與へるととなどはなく、夫々の形、用途に依つて 個々の名前をつけてるる。今東の方から主な島を順に舉げて說明するとととする。

I マーシァル群島一一籠全體を總稱する名前はないが、Enniwan と云ふ言葉が籠全體 を云ぶ時に使はれるここがある。本來の意味は Enn in wan 郎ち大切な品物 (=wan)を しまつて置く容れ物 (Enn=容器のてと) と云ふ意味である。マーシっルには棚子葉籠の外 木其の他でつくる箱をどはないので、タンス、長持、金庫其の他に相當する物も、食物を 入れる梖その他の曲物、籠及び食物を盛る食器等に當るものまで總べて楖子の葉を編んで 作る。從つて此等を總稱して Enni wan と云ふので決して梆子葉製籠と云ふ意味は含ま れてるない。との外パラウ島、ヤップ島の如く同じく椰子葉製籠の中に多くの名稱のある 所もポナペの如く尠い所も、何れに於ても夫々の形之用途の定つた一定のものに各々一つ

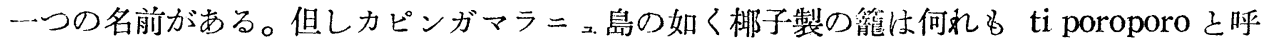
び、更に特定の種類のものを云ふ時は ti poroporo の後に ti poroporo ja păng と云ふ 如く形や用途を示す言葉を附加するものもあるが、之は例外に屬し、一般には形や用途に よつて違ふ一つ一つのものに對する名稱があるのみである。マーシっル群島では前逝の如

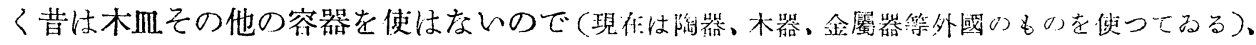
唯楖子桨製編物のみを使つてみたので、㯕子葉製編み箈の種類や名稱は甚だ多い。今下に 列舉すれば

(i) kilik in ekan一一第一類の (A) 軸を底とするものに屬し第 2 圖 aに示したのが之で ある。kilik と云ふ名のつくものは總べて第一類 $(\mathrm{A})$ 師ち軸を底とするものである。 ekan

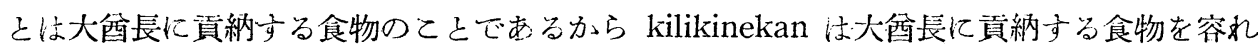
る kilik 型籠である。

(ii) kilik in ik- $\mathrm{ik}$ は魚、魚を容れて運ぶ kilik 籠、第一類 $(\mathrm{A})$ 飞屬す。

(iii) kilikin kere-一椰子の䐝を容れて運ぶ kilik 籠第一類 $(A)$ に屬す（第 2 薃 b)。

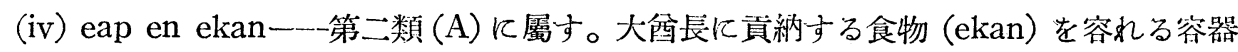
(eap)。

(v) eap en magai一第二類 (A)、食物 (magai) の容器。

(vi）nin chiron一一第二類中變異形に屬し、編み殘しを長く繩の如くなし、下げ紐の如 
くしたもの。娘のハンドバッグ。

(vii) nin rai一一第二類 (A) に屬すとは云へないまでに甚だしい變異形郎ち成熟葉を用 ひ、葉唡の固い部分を除き經、緯の二つを其のま」編み合す。砂利運びに用ふ(rai=砂利、 $\operatorname{nin}=$ 容れ物)。

(viii) Eap en Buiro I一一第二類 (A)

(ix) Eap en Buiro II——第二類 (D) 筆者の ポリネジア型と名付ける底の編み方の特異のも の(第 7 㯰)。(viii) と (ix) は名前は同じでも形は 大曫ちがふ。重要食料であるBuiro(質はマゴモ 染澌粉)を容れる籠と云ふ意味で名前は同じで あるが、形は全然別な二種類の籠である。

(x) Banenor一ーマゴモグ澱粉をこる芋を烟 から取つて家へ蓮ぶ籠。第二類 (A) に入る。

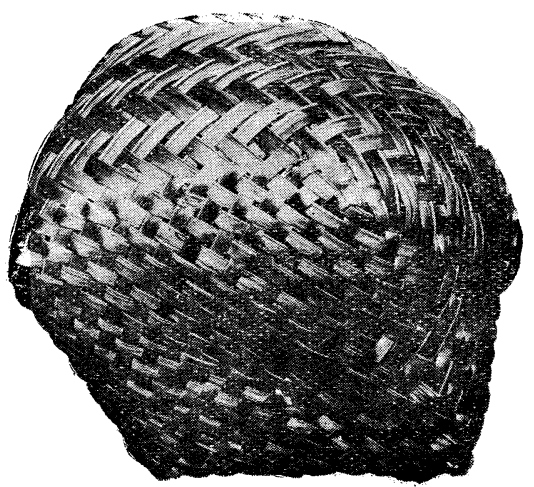

第 8 圖

(xi) Badri一一食物容れ、第二類 (A)にして多少變形されてるる。

(xii) Enmar一一魯籠第二類 (A) 亿屬す。

(xiii) Sonokonok一大切度物品を容れるもの。第二類 $(\mathrm{C})$ 神子葉製籠としては最も精 巧、入念沉つくるもの。

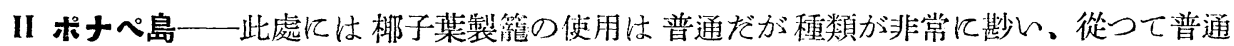

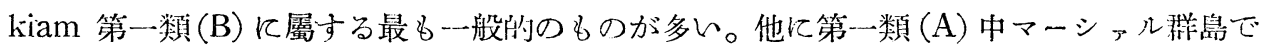
kilininkele と呼ばれる程類のものもあるが、他島より粭入したものでポナぺ本來のもので 效いと云ふ。圆型の第二類 $(\mathrm{A})$ に屬するものも稀れに見るが、他より來た人が使用するの でポナぺの人は使用せずと云ふ。 kiam の外には kopou と云ふ非常に特殊な編みうの全 物容れに使ふ梛子葉製籠がある。之はポナぺが原である。トラック島でも kopou と云つ て食物容れとして使つてるるが、ポナペより來をものであるてとを知つて使つてわる。

III トラック島一此處も篰の種類の尠い所である。

(i) djuk (truk) 一一第一類 (B) K屬し第 3 圖に示したものが之である。

(ii) margel一一第一類(B)の最も一般型に屬するもの。

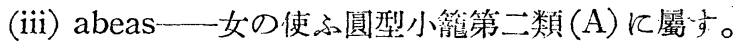

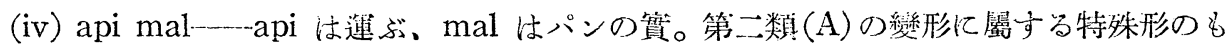
のを天稆棒の前後に二つ附けたるのである。

ての外にボナぺの kopou が使はれておる。 
IVヤッブ島一此處にも多くの種類が使用せられてるる。

(i) fonol一一第一類 (B) 亿屬する最も一般的なる。

(ii) sirigutsal-D-(i) と大體同じで大型。

(iii) tsal——sirigu tsal の tsal である。(ii) と同じで小形なり。

(iv) gilrou-一第一類 (B) 亿屬し手法は fonol，tsal と同じであるが、底が淺く一本の 葉唡についた葉を全部使用する。男子のみ持つ。

(v) dugen e ramog一一第一類 (B) 飞㻿すと云へるが變異形である。

(vi) gurvav——ーシァル群島の (vii) 砂利運び籠に似る、第二類としては變異が大き い。特に第三類をつくつてもよいが便宜上二類戀異形とする、成熟葉をとり、葉柄の固い 部分を去り、經、緯二つの材料を單純て斜め亿組み䋹みした小形な粗雜を籠。

(vii) tanerig一- (vi) yurvav に似てるるが編み殘しを長く繩の如く撚り下げ紐として ある。

(viii) gudgud e lav-一てれも（vi）yurvav に似てるるが形狀が違ふ。

(ix) lev一一てれ\& yurvav の最も甚だしく變形したものと云へる。一つ一つの旸狀葉 の葉柄てついてみる附根の所を少しあけて編む。此の手法を一層誇大して美しい形につく つたものがニューギニアにある。

(x) uai一第二類 (B) の代表的なものである。パラオ、ヤップでは常に手提を持つてる るととが禮式にかなふものとされてなる。

\section{V パラウ島}

(i) Chorovikl一一第二類 (A)に屬する代表的のものである。生寺等を之に入れて運ぶ所 埍芋バスケットである。

(ii) Sualo一第二類 (A)に屬す。煮た芋等食物を入れて置く圆の如をもの。

(iii) Chalais一一第一類 (B) 飞屬し細長い。

(iv) a uloig一一第一類 (B) 飞屬し。粗襍存もの。

(v) tengrik一一第二類の奱異形、編み殘しを繩の如く撚り下げ紐の如くなす。

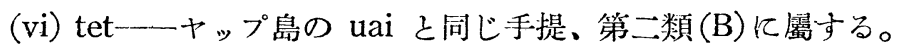

以上K於て I マーシァル群島、II ポナペ島、III トラック島、IVヤップ島、V パラウ

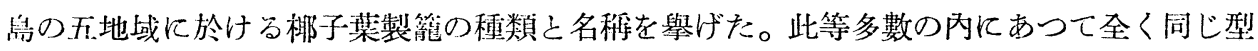
のものを同じ名稱で呼び同じ用途に使ふものはポナぺの kopou をトラックで使るものの みである。パラウとヤップは成年になつたら男女とも手提を持つて步くのを禮儀とされて みる。乙の慣相は兩方共に同じであるのに手提籍の名稱はヤップでは uai，パラウでは tet と云ふ。大體の編みうの原則は同じであるが詳細に云へば相遠はある。マーシェル群島で 
kilikinkele と云ふ第一類 (A)の最も發達したものは、梛子の實を入れて連ぶ籠としてポナ ペ以東には可なり廣く用ひられでる、然し其の名前は一樣でない。ヤップ島で sirigutsal, tsal, fonol 等と稱せられてるる。此の種の第一類 (B)に屬する籠は中央カロリン群島から 西カロリン群帠の多くの島々で何でも物を容れる時直ちに作つて使用せられるが、名稱は 同一で存い。斯くの如く全く同一の型の籠を同一の目的に使用する際も島に依つて名稱が 達つてるる。更に第二数の籠となると製作手法も用途も多少宛相違し、島に依つて變化が 甚だしん、從つて使用する時の使用感が大變暹ふ、故に名稱も當然違つてるる。

結語

筆者は昭和十二年以來十六年まで五回每夏三ケ月乃至五ケ月南洋群島の民族學的調査に 從事し、物質文化中何れの島にも普遍的飞使用されてるる梛子葉製籠の比較研究を思ひ立 つた。既て長谷部言人呚授の採集された標本に加へて、集め得られる限りのものを蒐集し て䂰究して見た。其の結果は前記した二三のものを除いては近隣の島と島との間に相似關 係が發見出來ないととになつた。作製技術に於て近隣の島同志の間に明瞭を一樣性が認め られるのは東部の kilikinkele と西部の tsal, fonol のみである。名棌に至ると全く相似の ものを見出し得ない。宗敉や社會組織や家屋等に於ては同じものが可なり廣い能園に同じ 系統の名稱を持つて行はれてるるのを見る。家具としての木箱の如きもトコベイ硨、ソン

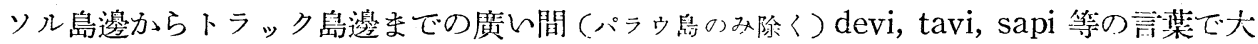

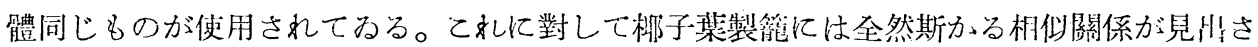

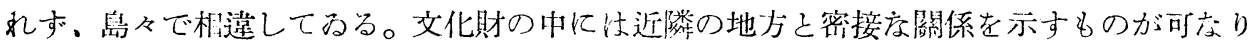

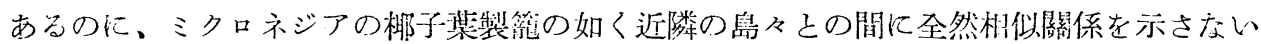
ものもある。斯くの如き相關關倠を示さない事例之云ふものがあるととは、物筫文化研究 上飞注意すべき事であると思ふ。此等の籠飞就いては簐者は其の製作、使用より使朋する 時の感じまで多少理解してるるので相關關係を示さないる云ふ否定現像の依つて來をる所

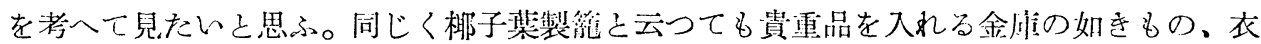
服を入れるタンスの如きもの、食料を蓮般する籠、食物を容れる槛の如きもの、等大々使 用する時の感じが全然違ふ。他滴虽な材料がをいため同じく㭋子葉でつくるのではある が、目的、用途沉從つて細い曫化の起るのも當然である。楖子葉編物は縓み方が非常飞制 限されるので㡩化が粆い。外來者は之を皆んな同じく梛子葉製編み箈として同棈に見る。 筜者も斯かる考へから蒐集して見たのであるが、調查が進むと從つて、外見は同じでも各

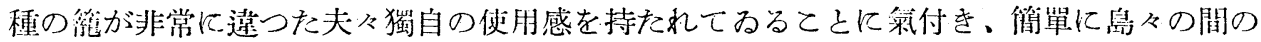

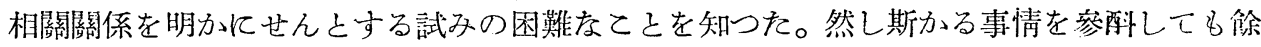
りに類似性がない。此の點に就いては改めて稿を起すてととする。 